\title{
PERANCANGAN APLIKASI UJIAN ONLINE BERBASIS WEBSITE
}

\author{
${ }^{1}$ Fritz Gamaliel, ${ }^{2}$ P. Yudi Dwi Arliyanto \\ ${ }^{1,2}$ Politeknik Meta Industri Cikarang \\ Jln. Inti 1 Blok C1 No 7 Lippo Cikarang 17550 \\ *e-mail:_ritzgamaliel@politeknikmeta.ac.id
}

Received: 2021-07-26, Revised: 2021-08-10, Accepted: 2021-08-22

\begin{abstract}
Abstrak
Sistem Informasi ujian secara online merupakan salah satu bagian sistem informasi pendidikan jarak jauh melalui media teknologi internet. Perguruan Tinggi menggunakan Moodle sebagai aplikasi ujian online penerimaan mahasiswa baru, dalam hal ini Moodle tidak terintegrasi dengan sistem internal Perguruan Tinggi. Konsep Ujian online yang tidak terkait ruang dan waktu dapat menjadi solusi atas kendala yang ada pada metode ujian yang konvensional. Proses Pengumpulan data menggunakan metode observasi, wawancara dan study pustaka. Dalam pengembangan sistem menggunakan metode Extreme Programming. Alat perancangan system yang di gunakan adalah Class diagram, dan Use case diagram. Sedangkan untuk pembuatan sistem informasi ujian secara online pada perguruan tinggi penulis menggunakan Bahasa pemograman yang digunakan adalah PHP dan MySQL sebagai databasenya. Berdasarkan hasil penelitian maka diperoleh sistem informasi ujian secara online pada perguruan tinggi. Soal yang disajikan dalam sistem pilihan ganda. Implementasi dari sistem ujian online ini dibuat dengan fasilitas meliputi manajemen soal ujian, manajemen ujian, manajemen data user, dan mengerjakan ujian yang nantinya akan menghasilkan keluaran nilai.
\end{abstract}

Kata kunci: Ujian Online, Website, PHP, MYSQL, Laravel

\section{Abstract}

The online exam information system is one part of the distance education system through internet technology media. Colleges use Moodle as an online application for new student admissions, in this case Moodle is not integrated with the College's internal system. The concept of an online exam that is not limited by space and time can be a solution to the obstacles that exist in conventional exam methods. The process of collecting data using the method of observation, interviews and literature study. In system development using the Extreme Programming method. System design tools used are Class diagrams, and Use case diagrams. Meanwhile, to create an online exam information system at the university, the author uses the PHP programming language and MYSQL database. Based on the results of the study, an online examination information system was obtained at universities. The questions are presented in a multiple choice system. The implementation of this online exam system is made with facilities including exam management, exam management, user data management, and taking exams which will produce value output.

Keywords: Online Exam, Website, PHP, MYSQL, Laravel

\section{PENDAHULUAN}

Di era revolusi industri 4.0 yang menjadikan teknologi sebagai wadah transformasi informasi dalam melaksanakan kegiatan sehari-hari. Perkembangan teknologi ini juga harus diikuti dengan perkembangan pada Sumber Daya Manusia (SDM). Manusia sebagai pengguna teknologi harus mampu memanfaatkan teknologi yang ada saat ini, maupun perkembangan teknologi tersebut selanjutnya. Adaptasi manusia dengan teknologi baru yang telah berkembang wajib untuk dilakukan melalui pendidikan. Hal ini dilakukan agar generasi penerus tidak tertinggal dalam hal teknologi baru. 
DOI: $10.52362 /$ jmijayakarta.v1i4.503

Dengan begitu, teknologi dan pendidikan mampu berkembang bersama seiring dengan adanya generasi baru sebagai penerus generasi lama. Beberapa cara adaptasi tersebut dapat diwujudkan dalam bentuk pelatihan maupun pendidikan.

Perguruan Tinggi merupakan salah satu instansi lembaga pendidikan. Dalam struktur organisasi Perguruan Tinggi mengambarkan tugas dan wewenang masing-masing bagian Prodi. Prodi merupakan salah satu unit yang ada di Perguruan Tinggi yang menangani aktifitas yang berkaitan dengan penyelenggaraan kegiatan belajar mengajar dan administrasi akademik bagi seluruh mahasiswa diantaranya melakukan kegiatan ujian akhir semester untuk mahasiswa.

Adapun dalam pelaksanaan ujian penerimaan mahasiswa baru selama ini menggunakan Moodle dimana belum terintegrasi dengan sistem internal Perguruan Tinggi. Jika ada mahasiswa baru yang mendaftar, maka admin kemudian meneruskan datanya secara manual ke dalam Moodle. Hal tersebut tidak efisien karena admin (manusia) rentan melakukan kesalahan.

Berdasarkan uraian yang telah dijelaskan di atas maka penulis mengangkat permasalahan tersebut sebagai judul penelitian, Adapun judul yang dibuat yaitu "Perancangan Aplikasi Ujian Online Berbasis Website".

\section{TINJAUAN LITERATUR}

Penelitian terdahulu dilakukan oleh Endri Rahmawanto yang berjudul "Sistem Informasi Ujian Mandiri Online Berbasis Web di SMPN 1 SRANDAKAN (Information Systems Web-based Online Self-Test in SMP N 1 Srandakan)" [1]. Berdasarkan penelitian tersebut yaitu penelitian menghasilkan sistem informasi ujian mandiri online berbasis web untuk menguji kemampuan siswa dalam menyerap pelajaran di sekolah

Penelitian terdahulu dilakukan oleh Nyimas dkk yang berjudul "Aplikasi Ujian Online Berbasis Web di SMA Bhakti Nusantara Palembang" [2]. Berdasarkan penelitian tersebut yaitu penelitian menghasilkan aplikasi ujian online pada SMA Bhakti Nusantara Palembang yang memudahkan siswa dalam melakukan ujian.

Penelitian terdahulu dilakukan oleh Heru dkk yang berjudul "Rancang Bangun Program Ujian Online pada SMP Saronggi 2 Dengan WebSite Design Method" [3]. Berdasarkan penelitian tersebut yaitu penelitian menghasilkan aplikasi ujian online pada SMA Bhakti Nusantara Palembang yang memudahkan siswa dalam melakukan ujian.

Penelitian terdahulu dilakukan oleh Dwinita Arwidiyarti yang berjudul "Aplikasi Ujian Online Berbasis Web Pada SMK Negeri 1 Tanjung" [4]. Berdasarkan penelitian tersebut yaitu proses ujian menjadi lebih cepat, praktis, meminimalisasi penggunaan sumber daya, hasil ujian pun akan didapat dengan cepat dengan tingkat akurasi yang lebih tinggi.

Penelitian terdahulu dilakukan oleh Ahmad Riyadi dkk yang berjudul "Pembuatan Aplikasi Sistem Ujian Online Pada SMK Garuda Nusantara Bekasi” [5]. Berdasarkan penelitian tersebut yaitu pembuatan aplikasi ini dapat membantu menyelesaikan masalah bagi manajemen sekolah dalam melakukan peningkatan efektifitas belajar mengajar dan pengelolaan nilai secara online dengan teknologi internet.

Penelitian terdahulu dilakukan oleh Dede Firmansyah Saefudin dkk yang berjudul "Rancang Bangun Aplikasi Ujian Online Studi Kasus: SMK 1 PGRI Cikampek" [6]. Berdasarkan penelitian tersebut yaitu dengan ujian online sekolah dapat mengurangi bahkan meminimalisir masalah-masalah yang terjadi pada pelaksanaan ujian konvensional (manual) karena dengan sistem komputer semua dapat dikelola dan dipantau lebih rapih secara mudah dan terpusat.

Penelitian terdahulu dilakukan oleh Nur Aminudin dan Irwan Susilo yang berjudul "Perancangan Sistem Aplikasi Ujian Online Berbasis Web Pada SMA Negeri 1 Kalirejo" [7]. Berdasarkan penelitian tersebut yaitu dengan sistem ujian online tidak perlu melakukan pengadaan kertas ujian dan menghemat waktu untuk koreksi ujian sehingga efisiensi dan efektitas yang menjadi tujuan pembuatan sistem ujian online dapat tercapai. 
DOI: $10.52362 /$ jmijayakarta.v1i4.503

Penelitian terdahulu dilakukan oleh Fathur Rohman dkk yang berjudul "Rancang Bangun Sistem Informasi Ujian Online Berbasis Web Menggunakan Metode Waterfall (Studi Kasus : SMK Darma Nusantara Pandeglang)" [8]. Berdasarkan penelitian tersebut yaitu dengan sistem ini pun mempermudah guru untuk membuat soal, menghemat biaya dan waktu dalam proses penilaian dan membuat laporan dengan mudah. Serta menghemat biaya daam pembuatan soal dan penggandaan soal ujian.

Penelitian terdahulu dilakukan oleh Annisa Fitrianti dkk yang berjudul "Aplikasi Ujian Online Dengan Metode Exteme Programming Pada MTs Al Muddatsiriyah" [9]. Berdasarkan penelitian tersebut yaitu sistem rancangan aplikasi ujian berbasis web ini, dapat menggantikan sistem ujian berbasis kertas dan bisa diakses oleh siswamenggunakan jaringan internet.

Penelitian terdahulu dilakukan oleh Catur Eko Purnomo dkk yang berjudul "Aplikasi Ujian Online Berbasis Intranet Pada Mata Pelajaran Simulasi Digital Di SMK Yadika 4 Ciledug" [10]. Berdasarkan penelitian tersebut yaitu siswa terbantu dalam proses ujian online ini karena tidak perlu lagi mengisi data diri dilembar kertas dan dapat segera mungkin melihat hasil ujiannya.

Penelitian terdahulu dilakukan oleh Sukma Ellyana Rosa dan Ari Kurniawan yang berjudul "Rancang Aplikasi Ujian Online Madrasah Aliyah Negeri Surabaya Berbasis Website dengan Framework Laravel" [11]. Berdasarkan penelitian tersebut yaitu dapat memberikan sebuah sistem yang dapat mempercepat dalam pengoreksian jawaban dari ujian yang telah diselesaikan oleh siswa, pemberian nilai untuk siswa dan juga penghematan penggunaan kertas untuk ujian.

Penelitian terdahulu dilakukan oleh Alvin Mahendra Kosa dkk yang berjudul "Perancangan Sistem Ujian Online Berbasis Web di SMP Negeri 01 Cikarang Selatan" [12]. Berdasarkan penelitian tersebut yaitu dengan adanya aplikasi ini menjadi hanya 30-45 menit untuk pengerjaan ujian yang mana mencakup proses penilaian dan penginputan data.

Penelitian terdahulu dilakukan oleh Imam Rangga Bakti dkk yang berjudul "Pembuatan Aplikasi Ujian Siswa di SMA Berbasis Web" [13]. Berdasarkan penelitian tersebut yaitu siswa lebih mudah dalam melakukan proses ujian karena proses ujian sudah menggunakan teknologi yang berbasis komputerisasi.

Penelitian terdahulu dilakukan oleh Deuis Nurpala dan Munawaroh yang berjudul "Perancangan Sistem Aplikasi Bank Soal pada Ujian Online Berbasis WEB (Studi Kasus : SMA NEGERI 1 CIBEBER)" [14]. Berdasarkan penelitian tersebut yaitu membuat kegiatan menjawab soal dan penilaian terhadap hasil ujian terkomputerisasi, sehingga data - data soal dan nilai dapat di simpan dalam komputer.

Penelitian terdahulu dilakukan oleh Mahendar Dwi Payana dan M. Bayu Wibawa yang berjudul "Sistem Ujian Online Tes Masuk Universitas Ubudiyah Indonesia Bagi Calon Mahasiswa Baru Berbasis Web Menggunakan CI (Code Igniter)" [15]. Berdasarkan penelitian tersebut yaitu mempermudah calon mahasiswa baru melaksanakan ujian dan membantu mempermudah petugas ujian dalam merekap dan menghasilkan hasil ujian.

Mengacu penelitian-penelitian diatas maka dalam penelitian ini akan dilakukan penelitian suatu aplikasi ujian online berbasis web. Sedangkan sistem yang akan dibangun adalah tipe soal bertipe pilihan ganda, konfigurasi penyajian ujian, mengerjakan ujian, dan keluaran hasil ujian. Adapun soal dapat berupa teks, gambar, audio, video.

\section{METODE PENELITIAN}

Mengenai metode penelitian yang dilakukan penulis ada beberapa metode yang dilakukan, yaitu :

1. Wawancara (Interview). Wawancara merupakan teknik pengumpulan data yang dilakukan melalui tatap muka dan tanya jawab langsung antara pengumpul data ataupun peneliti terhadap nara sumber atau sumber data. Wawancara terbagi atas wawancara terstruktur dan tidak terstruktur.

2. Observasi. Observasi merupakan salah satu metode pengumpulan data dengan langsung terjun kelapangan untuk mengamati permasalahan yang terjadi dalam perusahaan secara

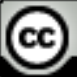


DOI: $10.52362 /$ jmijayakarta.v1i4.503

langsung ditempat kejadian. Adapun observasi yang dilaksanakan di Perguruan Tinggi, khususnya pada bagian Penerimaan Mahasiswa Baru.

3. Studi Pustaka. Dengan metode ini membantu penulis dalam pembuatan tugas akhir yang ditunjang dengan beberapa buku dan leteratur yang berkaitan dengan materi yang dibuat dalam penyusun tugas akhir ini.

4. Perancangan. Perancangan aplikasi adalah pembuatan rancangan aplikasi yang berkaitan dengan fungsionalitas dan fasilitas.

\section{HASIL DAN PEMBAHASAN}

\subsection{Use Case Aplikasi Ujian Online}

Berikut merupakan use case diagram aplikasi ujian online berbasis web

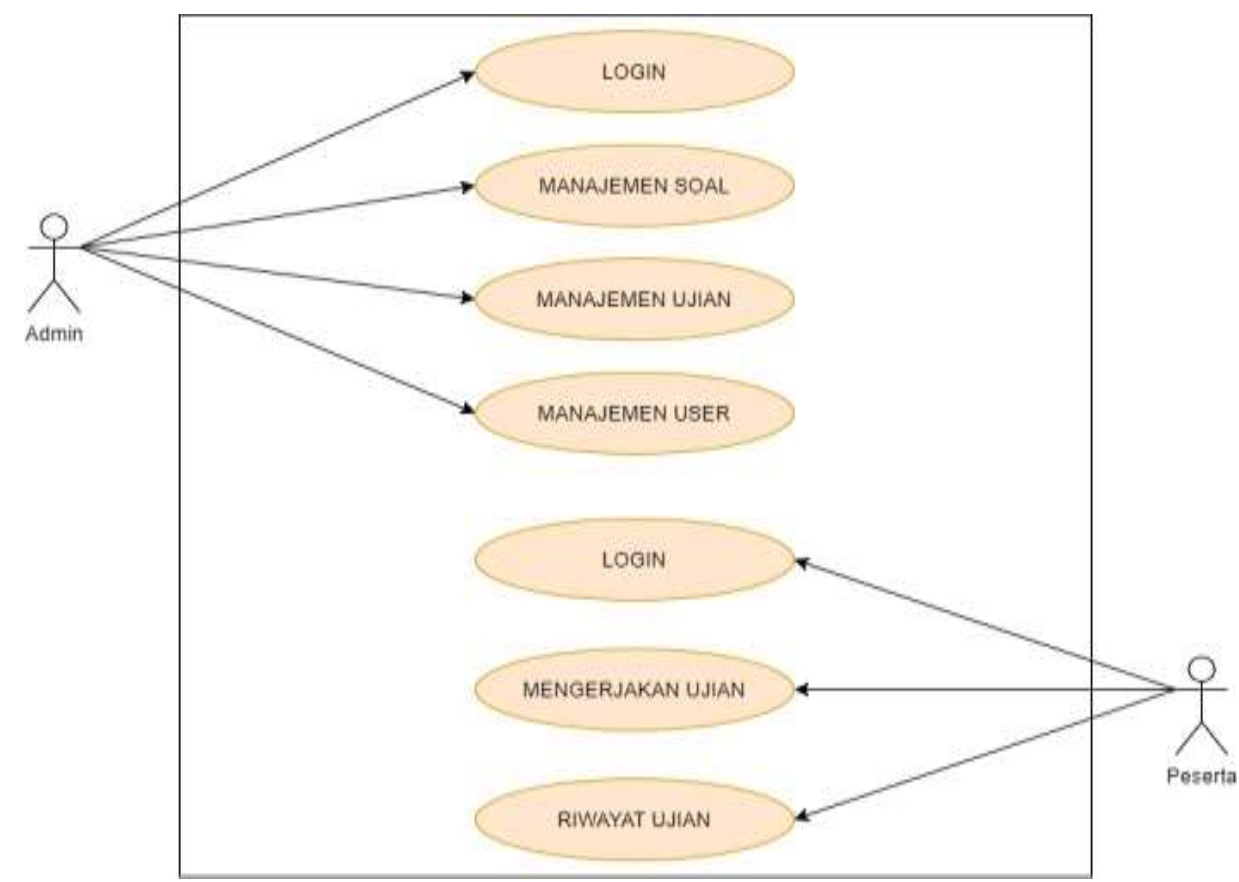

Gambar 1 Rancangan Use Case Diagram

Admin melakukan pengelolahan terhadap aplikasi ujian online berbasis web yang meliputi manajemen soal, manajemen ujian, dan manajemen user. Soal yang dikelola yaitu soal multiplechoice. Data ujian yang dikelola yaitu informasi ujian, dan konfigurasi penyajian ujian

Peserta ujian pertama kali diwajibkan untuk login ke dalam aplikasi ujian online agar bisa mengikuti proses ujian, peserta ujian memilih ujian sesuai dengan jadwal ujian, kemudian mengerjakan ujiannya dengan baik, dan setelah selesai siswa mendapatkan hasil ujian berupa nilai.

\subsection{Class Diagram Aplikasi Ujian Online}

Berikut merupakan class diagram aplikasi ujian online berbasis web 
DOI: $10.52362 /$ jmijayakarta.v1i4.503
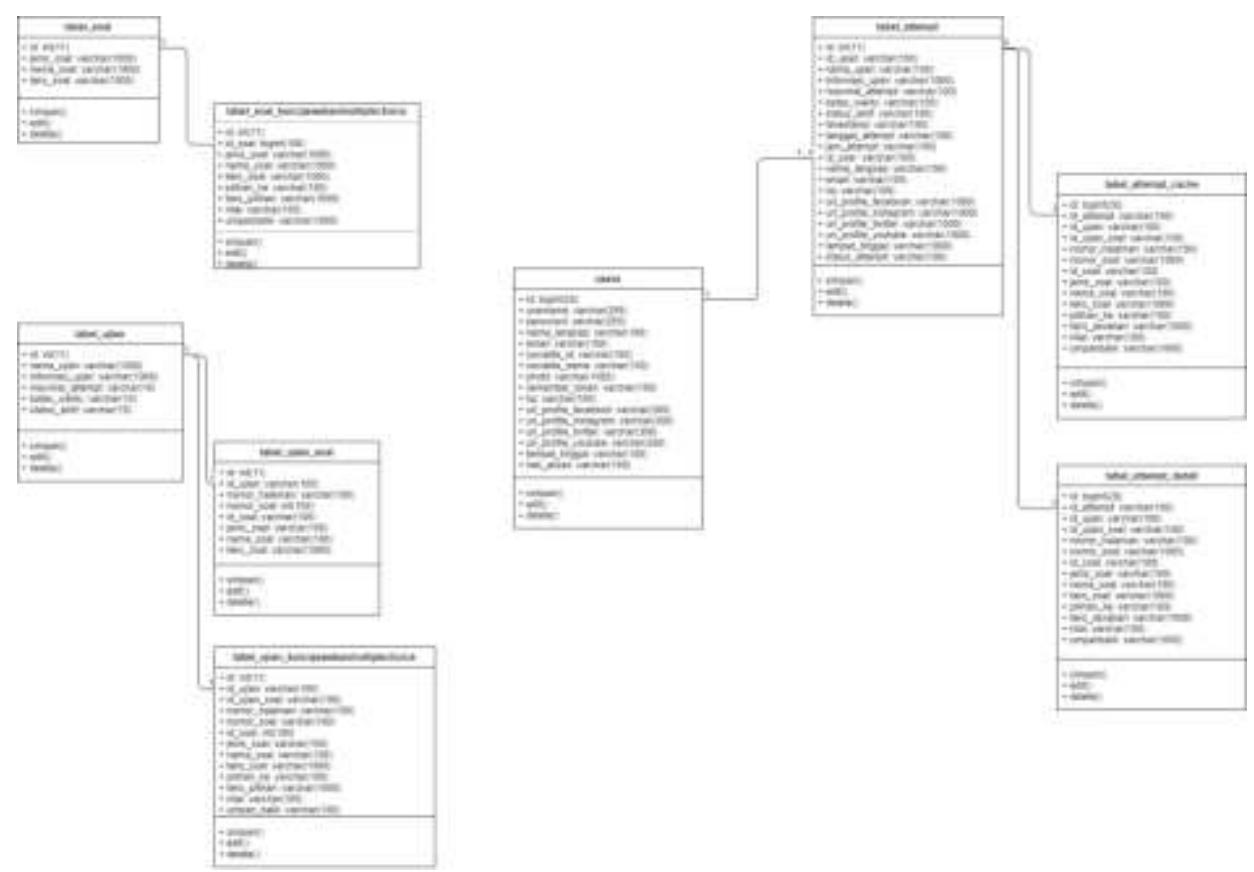

Gambar 2 Rancangan Class Diagram

\subsection{Tampilan Halaman Login}

Digunakan untuk user login ke dalam aplikasi ujian online berbasis web. Tampilan halaman login dapat dilihat pada gambar berikut.

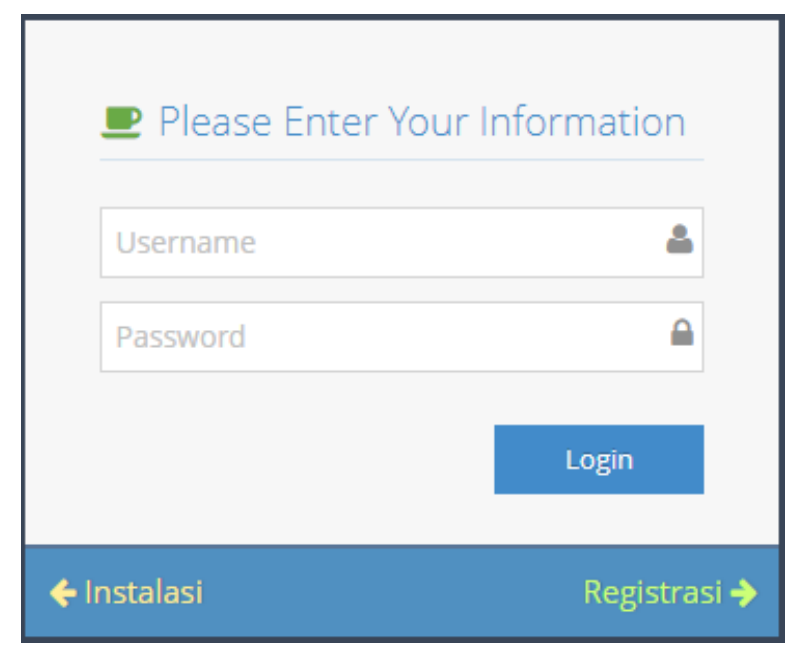

Gambar 3 Tampilan Halaman Login

\subsection{Tampilan Halaman Registrasi}

Digunakan untuk peserta mendaftarkan data dirinya ke dalam aplikasi ujian online berbasis web. Tampilan halaman registrasi dapat dilihat pada gambar berikut

\section{(2)}

This work is licensed under a Creative Commons Attribution 4.0 International License.

http://journal.stmikjayakarta.ac.id/index.php/JMIJayakarta 
DOI: 10.52362/jmijayakarta.v1i4.503

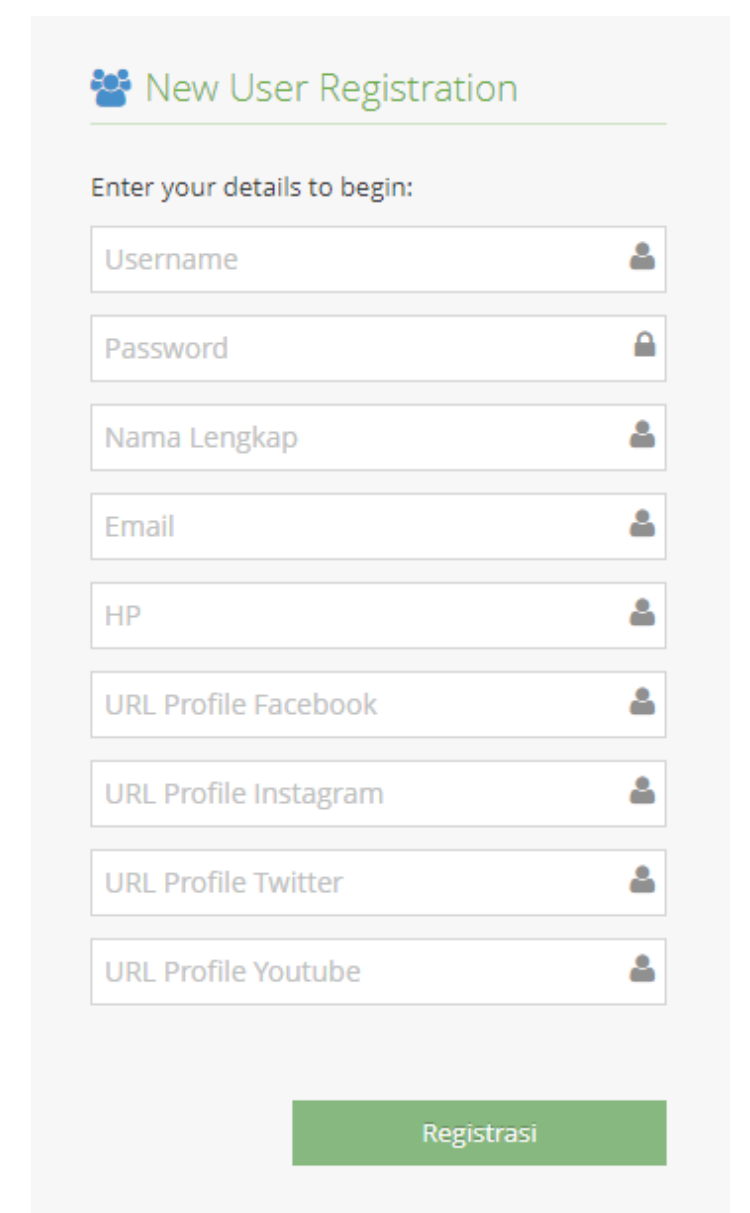

\section{Gambar 4 Tampilan Halaman Registrasi}

\subsection{Tampilan Halaman Menu List User}

Digunakan untuk admin melihat daftar peserta ujian yang telah terdaftar di dalam aplikasi ujian online berbasis web. Tampilan halaman menu data user dapat dilihat pada gambar berikut. 
DOI: 10.52362/jmijayakarta.v1i4.503

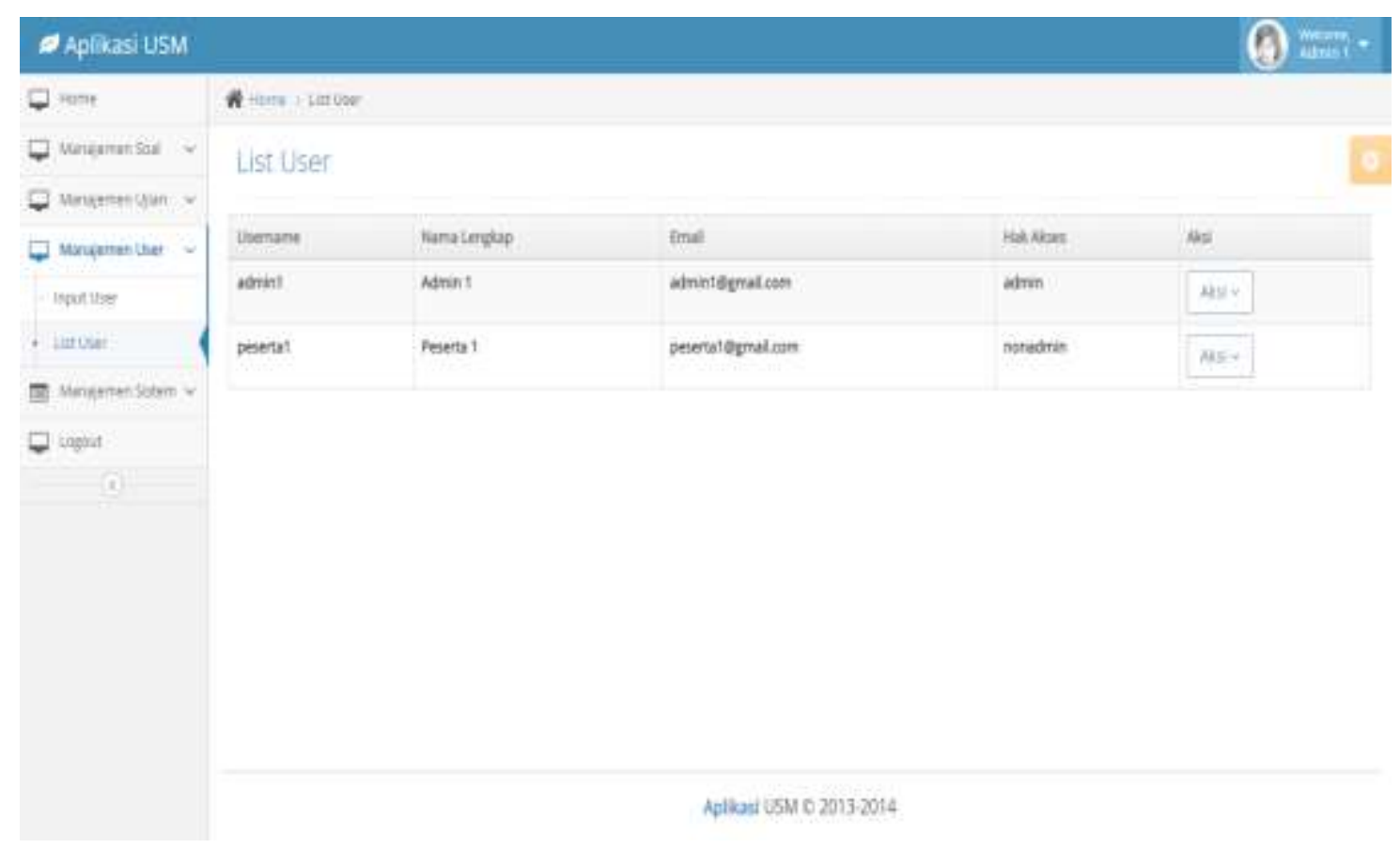

Gambar 5 Tampilan Halaman List User

\subsection{Tampilan Halaman Menu Input Data User}

Digunakan untuk admin mendafarkan data diri peserta ujian ke dalam aplikasi ujian online berbasis web secara manual. Tampilan halaman menu input data user dapat dilihat pada gambar berikut.

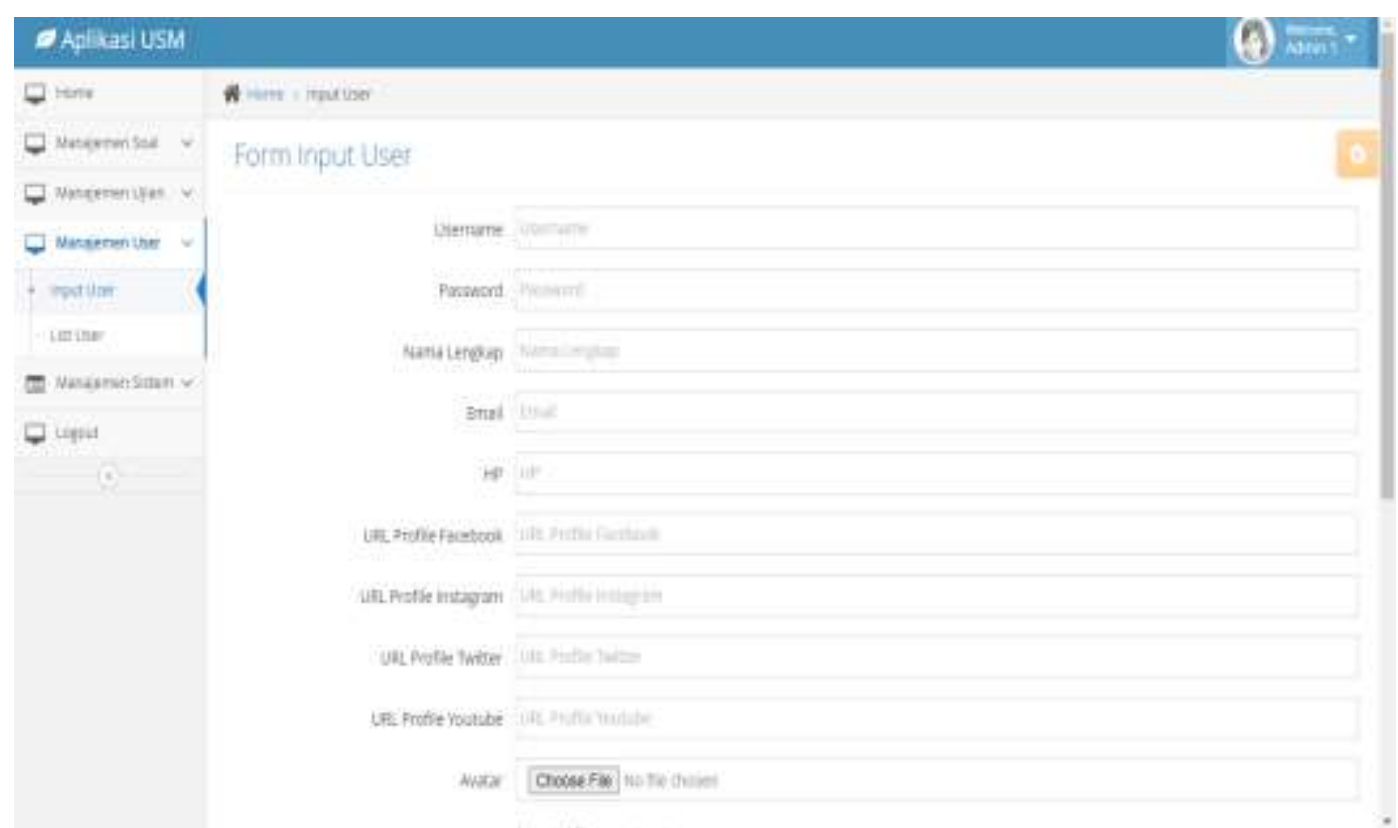

Gambar 6 Tampilan Halaman Menu Input Data User

This work is licensed under a Creative Commons Attribution 4.0 International License.

http://journal.stmikjayakarta.ac.id/index.php/JMIJayakarta 
DOI: $10.52362 /$ jmijayakarta.v1i4.503

\subsection{Tampilan Halaman Input Soal Ujian Multiple Choice}

Digunakan untuk admin menginputkan soal ujian multiplechoice ke dalam aplikasi ujian online. Tampilan halaman menu input soal ujian multiple choice dapat dilihat pada gambar berikut.

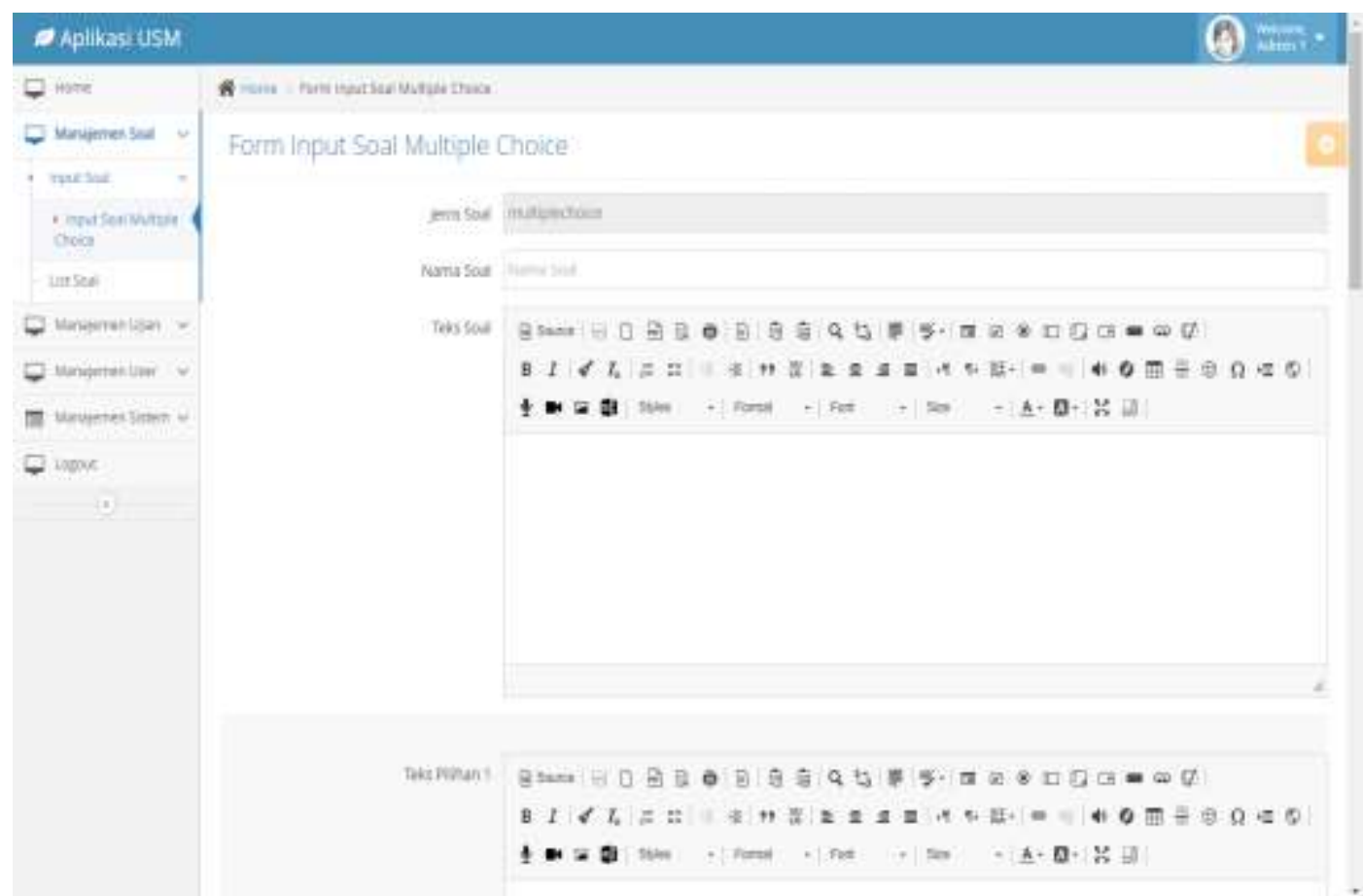

Gambar 7 Tampilan halaman input Soal Ujian Multiple Choice

\subsection{Tampilan Halaman List Soal Ujian}

Digunakan untuk admin melihat daftar soal ujian yang sudah ada di dalam aplikasi ujian online berbasis web. Tampilan halaman menu list soal ujian dapat dilihat pada gambar berikut. 
DOI: 10.52362/jmijayakarta.v1i4.503

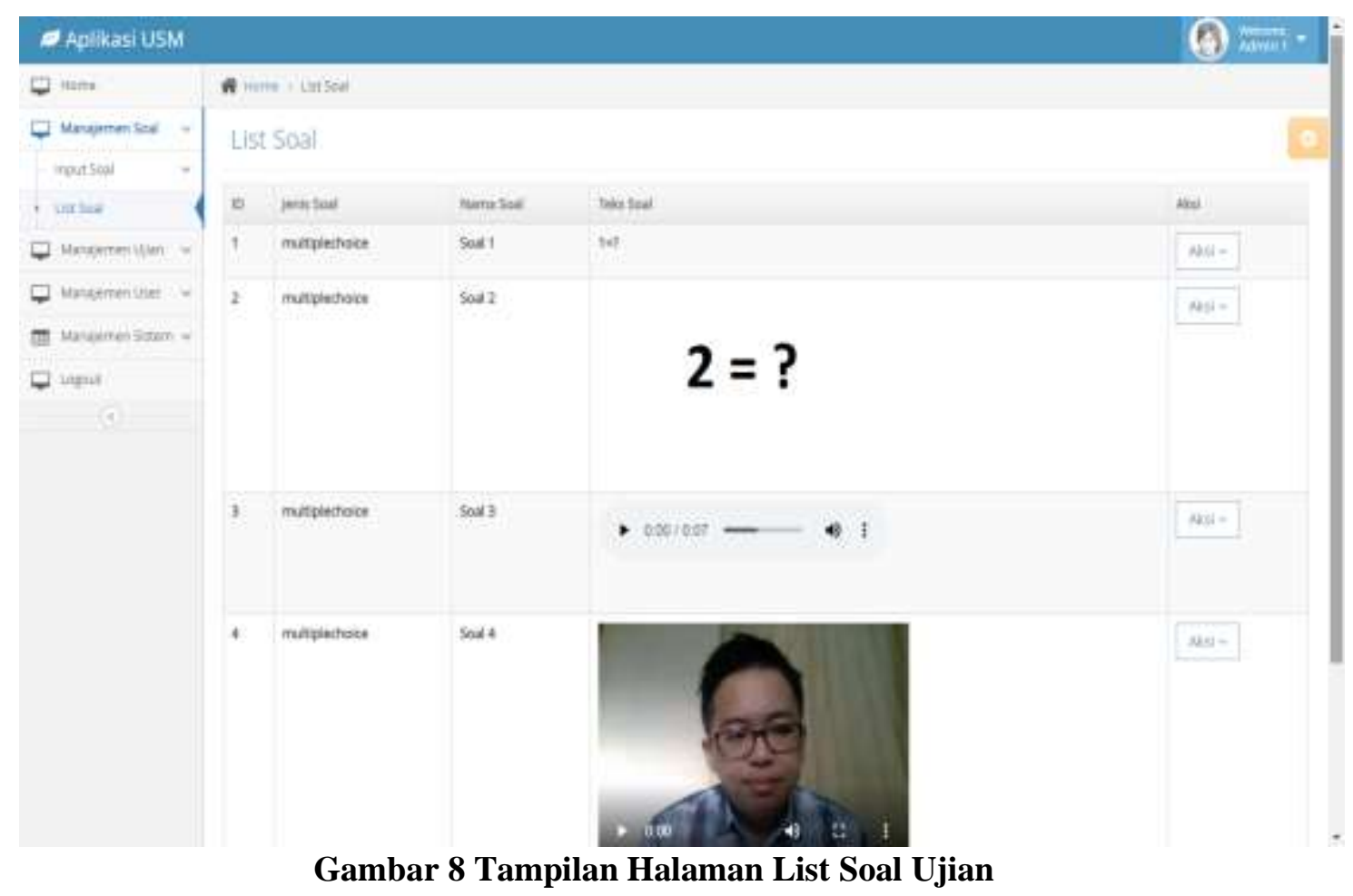

\subsection{Tampilan Halaman Input Ujian}

Digunakan untuk admin menginputkan ujian ke dalam aplikasi ujian online berbasis web. Tampilan halaman menu input ujian dapat dilihat pada gambar berikut.

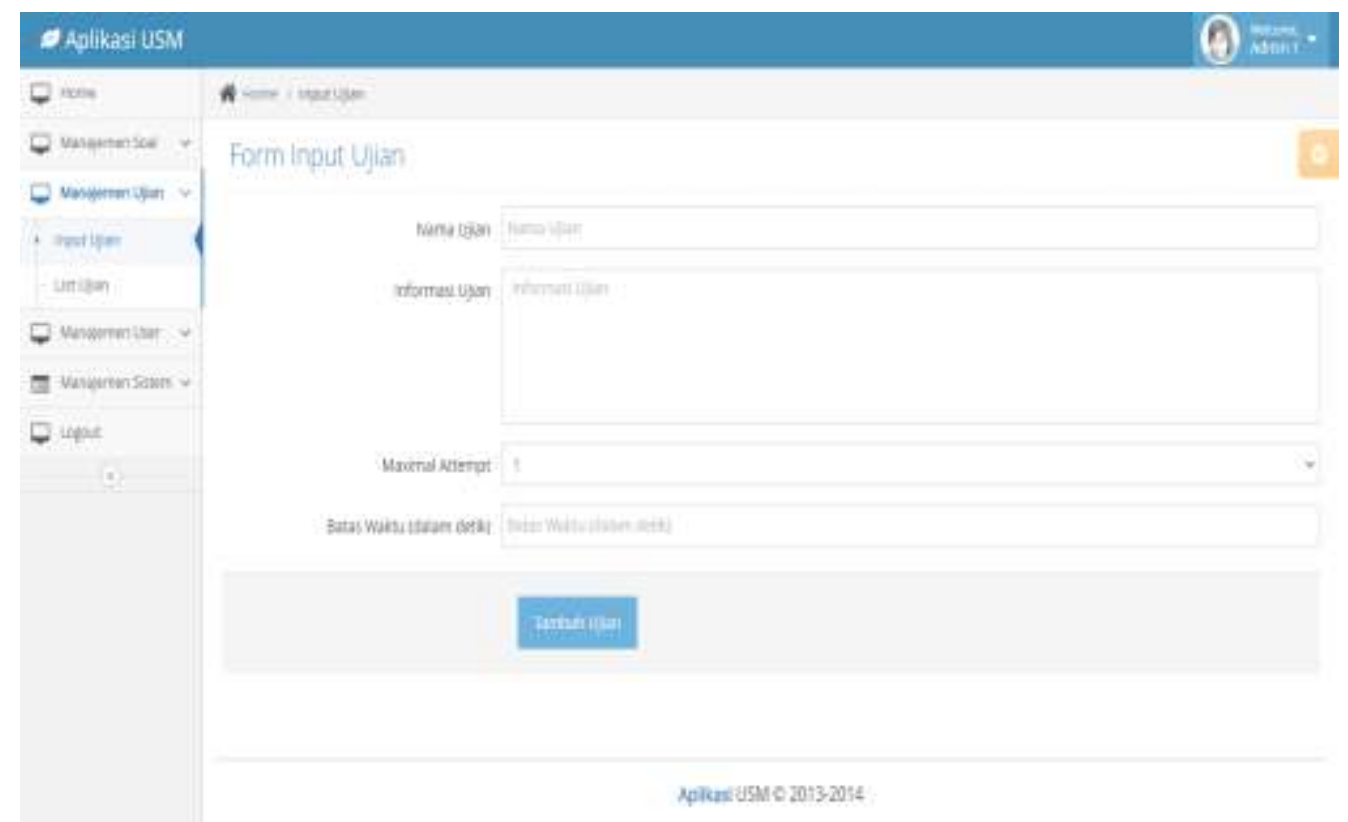

Gambar 9 Tampilan Halaman Input Ujian

This work is licensed under a Creative Commons Attribution 4.0 International License.

http://journal.stmikjayakarta.ac.id/index.php/JMIJayakarta 
DOI: $10.52362 /$ jmijayakarta.v1i4.503

\subsection{Tampilan Halaman List Ujian}

Digunakan untuk admin melihat daftar ujian yang sudah ada di dalam aplikasi ujian online berbasis web. Tampilan halaman menu list ujian dapat dilihat pada gambar berikut.

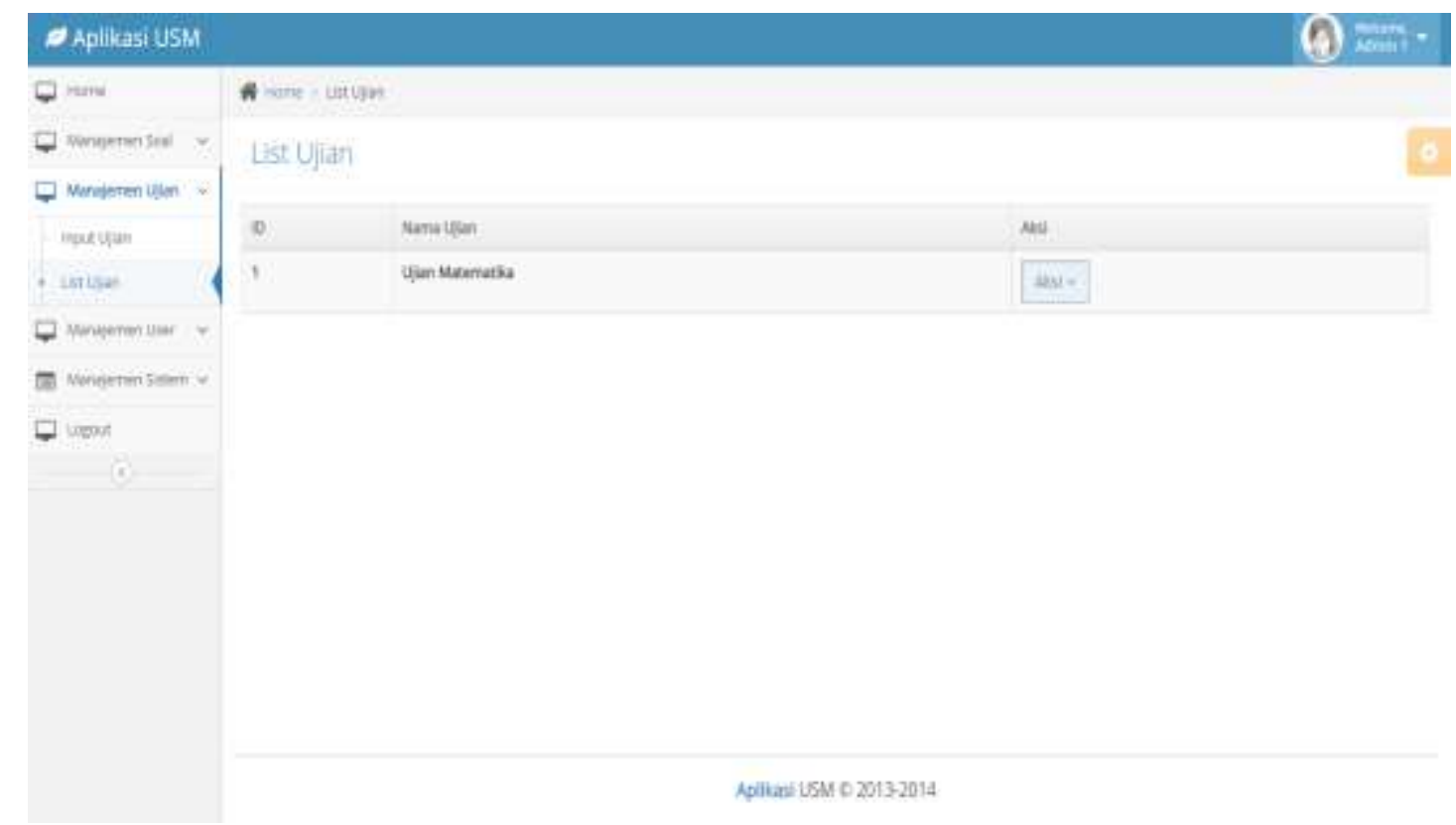

\section{Gambar 10 Tampilan Halaman List Ujian}

\subsection{Tampilan Halaman Konfigurasi Penyajian Ujian}

Digunakan untuk admin mengkonfigurasi penyajian suatu ujian yang ada di dalam aplikasi ujian online berbasis web. Adapun pada halaman ini dilengkapi dengan filter dimana jika suatu ujian sudah pernah dikerjakan sebelumnya oleh peserta ujian maka konfigurasi penyajian ujian tersebut tidak dapat diedit. Tampilan halaman menu konfigurasi penyajian ujian dapat dilihat pada gambar berikut.

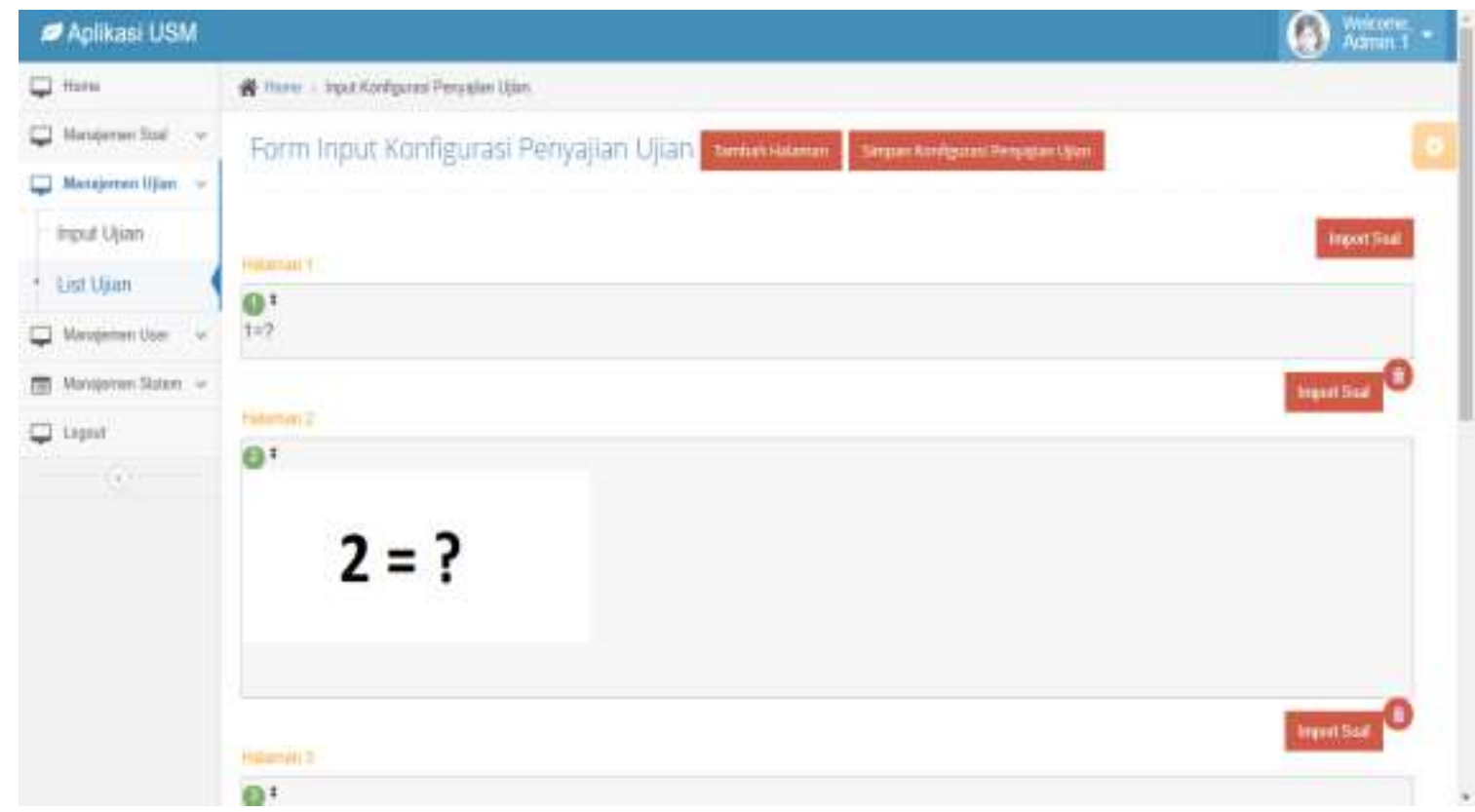

This work is licensed under a Creative Commons Attribution 4.0 International License.

http://journal.stmikjayakarta.ac.id/index.php/JMIJayakarta 
DOI: $10.52362 /$ jmijayakarta.v1i4.503

\section{Gambar 11 Tampilan Halaman Konfigurasi Penyajian Ujian}

\subsection{Tampilan Halaman Mengerjakan Ujian}

Digunakan untuk peserta ujian mengerjakan ujian yang ada di dalam aplikasi ujian online berbasis web. Adapun pada halaman ini dilengkapi dengan fungsi penghitung waktu mundur dan fungsi backup jawaban peserta ujian. Adapun fungsi penghitung waktu mundur digunakan untuk menghitung mundur waktu ujian sehingga apabila waktu ujian sudah habis maka peserta ujian tidak dapat melanjutkan lagi pengerjaan ujiannya. Sedangkan fungsi backup jawaban peserta ujian digunakan untuk membackup jawaban peserta ujian sehingga apabila di tengah jalan peserta ujian mengalami gangguan koneksi internet atau mengalami listrik mati maka peserta tidak perlu mengerjakan ulang dari awal. Tampilan halaman menu mengerjakan ujian dapat dilihat pada gambar berikut.

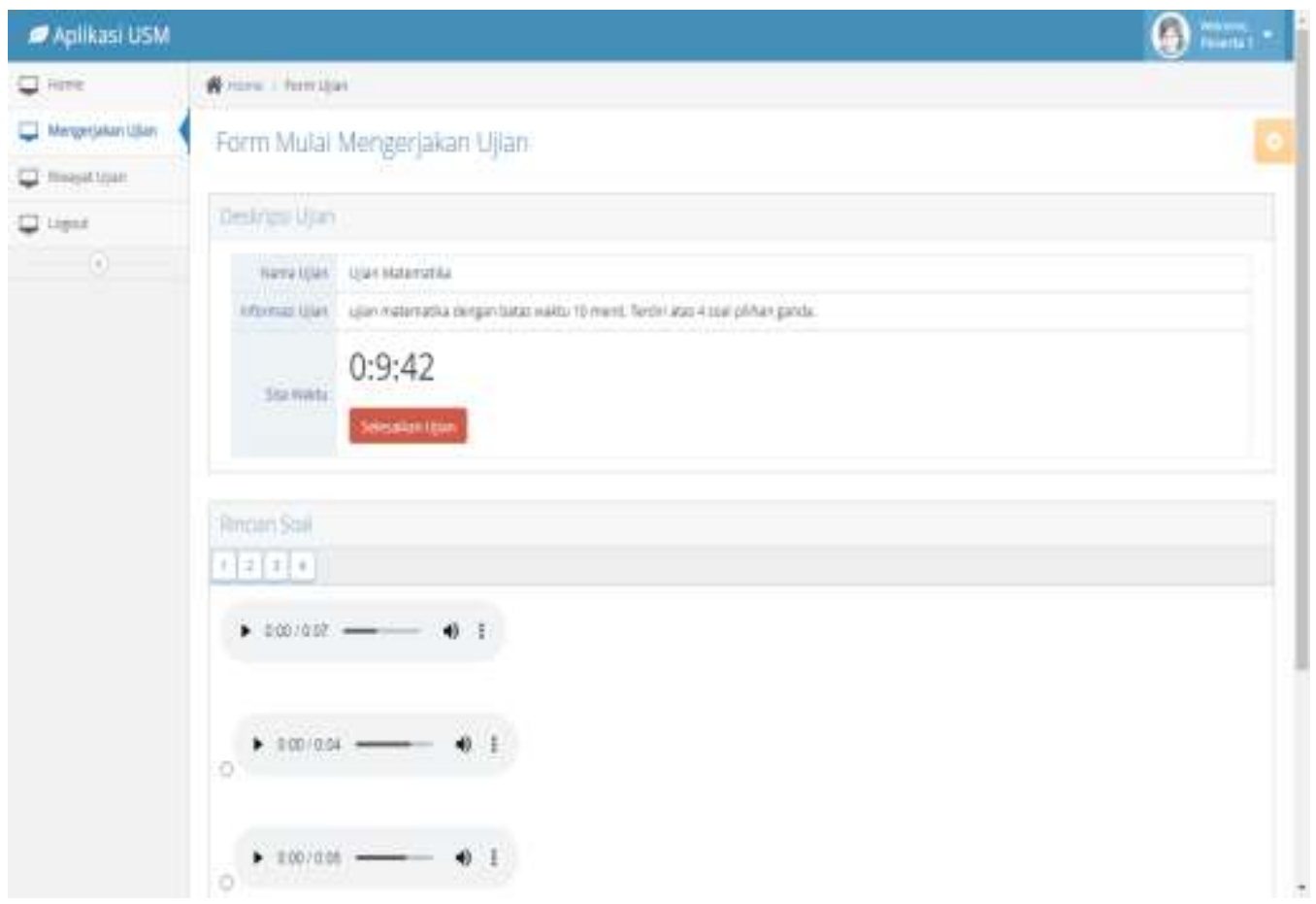

Gambar 12 Tampilan Halaman Mengerjakan Ujian

\subsection{Tampilan Halaman Riwayat Mengerjakan Ujian}

Digunakan untuk peserta ujian melihat riwayat ujian yang pernah dikerjakan sebelumnya pada aplikasi ujian online berbasis web. Tampilan halaman menu riwayat mengerjakan ujian dapat dilihat pada gambar berikut. 
DOI: $10.52362 /$ jmijayakarta.v1i4.503

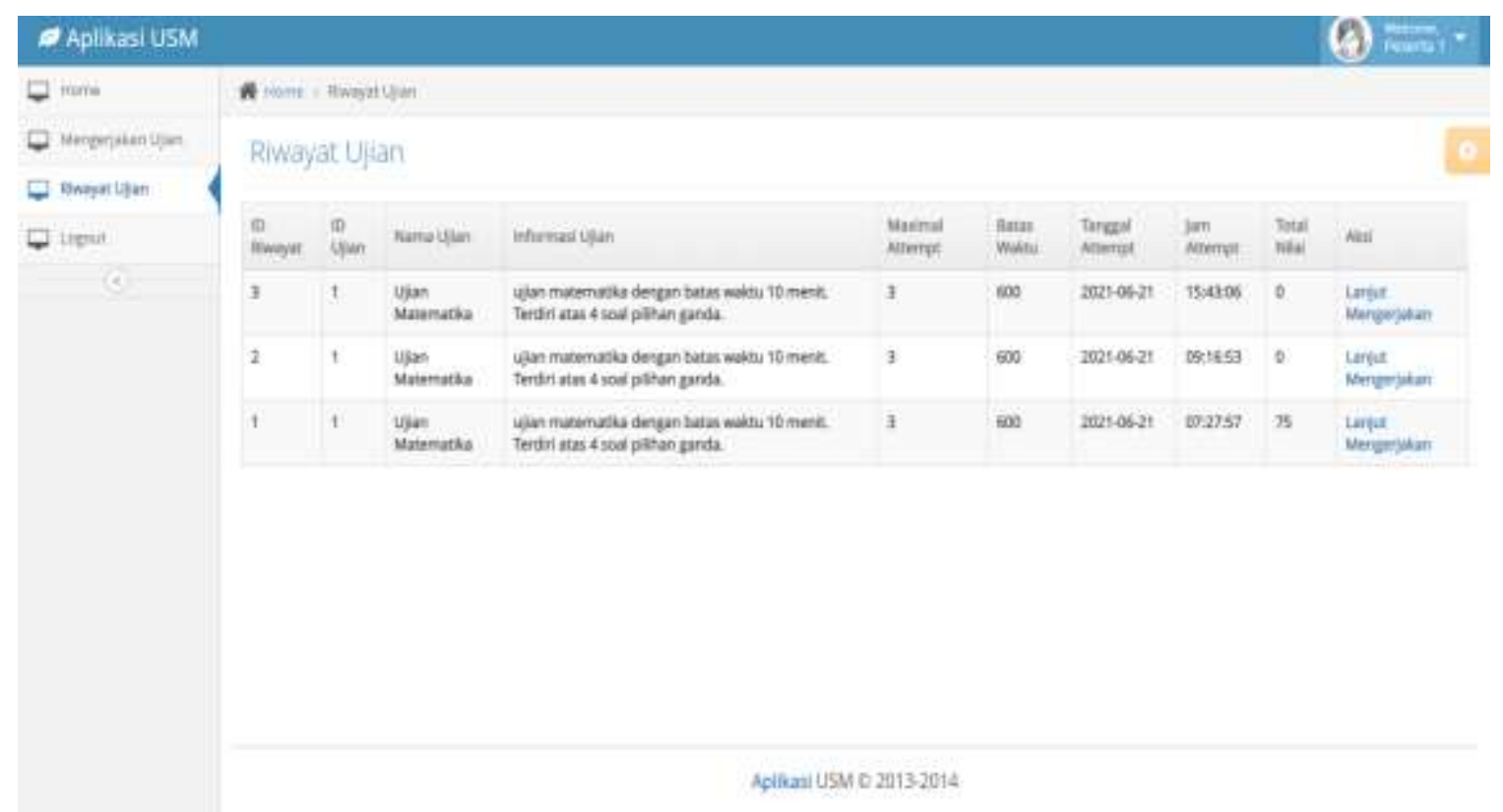

Gambar 13 Tampilan Halaman Riwayat Mengerjakan Ujian

\section{KESIMPULAN}

Berdasarkan hasil pembahasan dari bab-bab sebelumnya pada penelitian di Perguruan Tinggi maka penulis mengambil kesimpulan yaitu :

1. Sistem yang dibuat dapat berjalan sesuai fungsi dan aliran data yang telah di rancang.

2. Sistem Informasi Ujian Secara Online dapat diakses dengan web browser dan berdasarkan pengujian terhadap aplikasi yang dibuat, seluruh fungsi menu yang ada dalam aplikasi tersebut telah berhasil sesuai dengan fungsinya.

\section{REFERENSI}

[1] Endri Rahmawanto dan Dewi Soyusiawaty. 2015. Sistem Informasi Ujian Mandiri Online Berbasis Web di SMPN 1 SRANDAKAN. Jurnal Sarjana Teknik Informatika

[2] Nyimas dkk. 2020. Aplikasi Ujian Online Berbasis Web di SMA Bhakti Nusantara Palembang. Jurnal Ilmiah Matrik

[3] Heru dkk. 2018. Rancang Bangun Program Ujian Online pada SMP Saronggi 2 Dengan WebSite Design Method. Jurnal Komputer dan Informatika Akademi Bina Sarana Informatika

[4] Dwinita Arwidiyarti. 2019. Aplikasi Ujian Online Berbasis Web Pada SMK Negeri 1 Tanjung. Jurnal Teknologi, Rekayasa Sistem dan Komputer

[5] Ahmad Riyadi dkk. 2019. Pembuatan Aplikasi Sistem Ujian Online Pada SMK Garuda Nusantara Bekasi. Jurnal Ilmiah Sinus

[6] Dede Firmansyah Saefudin. 2020. Rancang Bangun Aplikasi Ujian Online Studi Kasus: SMK 1 PGRI Cikampek. Jurnal Teknologi dan Open Source

[7] Nur Aminudin dan Irwan Susilo. 2019. Perancangan Sistem Aplikasi Ujian Online Berbasis Web Pada SMA Negeri 1 Kalirejo. Aisyah Journal Of Informatics and Electrical Engineering

[8] Fathur Rohman dkk. 2018. Rancang Bangun Sistem Informasi Ujian Online Berbasis Web Menggunakan Metode Waterfall (Studi Kasus : SMK Darma Nusantara Pandeglang). Indonesian Journal on Networking and Security 
DOI: $10.52362 /$ jmijayakarta.v1i4.503

[9] Annisa Fitrianti. 2020. Aplikasi Ujian Online Dengan Metode Exteme Programming Pada MTs Al Muddatsiriyah. Informatics For Educators and Professionals

[10] Catur Eko Purnomo dkk. 2019. Aplikasi Ujian Online Berbasis Intranet Pada Mata Pelajaran Simulasi Digital di SMK Yadika 4 Ciledug. Jurnal Pengkajian dan Penerapan Teknik Informatika

[11] Sukma Ellyana Rosa dan Ari Kurniawan. 2020. Rancang Bangun Aplikasi Ujian Online Madrasah Aliyah Negeri Surabaya Berbasis Website dengan Framework Laravel. Jurnal Manajemen Informasi

[12] Alvin Mahendra Kosa dkk. 2019. Perancangan Sistem Ujian Online Berbasis Web di SMP Negeri 01 Cikarang Selatan. Jurnal Sibernetika

[13] Imam Rangga Bakti dkk. 2021. Pembuatan Aplikasi Ujian Siswa di SMA Berbasis Web. Jurnal of Software Engineering, Computer Science and Information Technology

[14] Deuis Nurpala dan Munawaroh. 2020. Perancangan Sistem Aplikasi Bank Soal pada Ujian Online Berbasis WEB (Studi Kasus : SMA NEGERI 1 CIBEBER). Journal of Artificial Intelligence and Innovative Applications

[15] Mahendar Dwi Payana dan M. Bayu Wibawa. 2020. Sistem Ujian Online Tes Masuk Universitas Ubudiyah Indonesia Bagi Calon Mahasiswa Baru Berbasis Web Menggunakan CI (Code Igniter). Journal of Informatics and Computer Science 